\title{
Rekomendasi Pengadaan Obat dan Alat Kesehatan Dengan Fuzzy Database (Studi kasus: Instalasi Farmasi Klinik Utama Cideng Medical Center)
}

\author{
Kamal Maulana Adha ${ }^{1}$, Susi Widyastuti*2 \\ ${ }^{1,2}$ Teknik Informatika, STIKOM Poltek Cirebon, Indonesia \\ e-mail corresponden*: miss_siwy@yahoo.com
}

\begin{abstract}
Abstrak
Kemudahan dalan melakukan pencarian terhadap persediaan obat dan alat kesehatan untuk pengadaan yang sesuai standar persyaratan mutu pada Instalasi Farmasi merupaka salah satu faktor kunci dalam menunjang pelayanan apa lagi dalam pencarian tersebut dapat direpresentasikan kedalam bahasa sehari-hari semisal: mahal, hampir habis, ataupun banyak oleh karena itu perlu adanya teknik informasi untuk mewujudkannya karena hingga saat ini belum ada suatu penerapan metode untuk permasalahn tersebut terutama di Instalasi Klinik Utama Cideng Medical Center.

Metode Fuzzy Database yaitu, suatu sistem basis data yang menggunakan teori himpunan fuzzy ke dalam Databases untuk menghasilkan informasi, dengan demikian pencarian persediaan obat dan alat kesehatan di Database dapat direpresentasikan kedalam bahasa sehari-hari.Maka Fuzzy Database sangat sesuai untuk di terapkan dalam Database pencarian obat dan alkes sebagai rekomendasi pengadaan di Insatalasi Farmasi Klinik Utama Cideng Medical Center, karena pencarian obat dan alat kesehatan itu begitu kompleks, akan sangat mudah apabila bisa dikomunikasikan dalam keseharian kita.
\end{abstract}

Kata kunci-Fuzzy Database, Fuzzy, Linguistik, Pencarian.

\begin{abstract}
Ease role in their search for supplies of medicines and medical equipment for the procurement of the appropriate standard quality requirements at the pharmacy installation merupaka one key factor in supporting the service of what else in such searches can direpresntasikan into everyday language such as: expensive, running low, or much by Hence the need for technical information to make it happen because until now there has been no method for an application such permasalahn especially in Installing the Main Clinic Cideng Medical Center.

Fuzzy Database that is, a database system that uses fuzzy set theory into Databases to produce information, thus finding supplies drugs and medical devices in the database can be represented into everyday language. So Fuzzy Database is very suitable to apply in its search database of drugs and medical supplies as recommendations on the procurement of Clinical Pharmacy Top Insatalasi Cideng Medical Center, because the search medicines and medical equipment is so complex, it would be very easy if could be communicated in our daily lives.
\end{abstract}

Keywords-Fuzzy Database, Fuzzy, Linguistik, Searching

\section{PENDAHULUAN}

Industri farmasi di Indonesia telah berkembang pesat sehingga semakin banyaknya bisnis jasa dan layanan apotek sekarang ini yang tentunya menimbulkan efek ekonomi pasar yang semakin ketat dalam persaingannya, banyak faktor kunci yang dapat menjadi pembeda agar bisa 
memenangkan pasar, salah satunya apotek yang memiliki pengelolaan informasi pengadaan obat dan alat kesehatan yang mudah untuk pengambilan keputusan. Berkaitan dengan pengadaan obat dan alat kesehatan yang begitu kompleks dan juga bervariasi, akan sangat sulit dalam proses pengadaanya, sedangkan pengadaan harus segera dilakukan demi kelancaran pelayanan, sehingga dengan metode Fuzzy Database lah dapat mengatasi masalah-masalah yang samar dimana bisa dikomunikasikan dalam keseharian kita dengan teknik memasukan Fuzzy ke dalam Databases semisal, mahal, hampir habis, ataupun banyak, hal tersebut tidak bisa didapatkan jika hanya menggunakan Database standar, oleh karenanya Fuzzy Database akan dapat menyelesaikan masalah-masalah ketidak pastian tersebut.

Sebagai contoh di Instalasi Farmasi Klinik Utama Cideng Medical Center ingin mengadakan pengadaan obat dan alat kesehatan yang pada implementasinya tidakhanya bisa menampilkan atribut-atribut standar, elainkan juga dapat membantu memberikan pilihan bagi instalasi farmasi berdasarkan standar kualifikasi persyaratan mutu yang diinginkan oleh pengadaan obat dan alat kesehatan, agar instalasi farmasi lebih mudah dalam memberikan kriteria yang didinginkan, maka penyampaian informasi tentang kriteria suatu atribut ingin direpresntasikan dengan menggunakan bahasa sehari-hari. Pada instalasi farmasi klinik utama cideng medical center selama ini dalam hal pengadaan obat dan alat kesehatan tidak menentu dan acak masih mengandalkan perkiraan saja dan tidak menggunakan metode yang jelas sehingga memungkinkan proses tersebut pengerjaannya berdampak pada pelayanan yang kurang maksimal. Penelitian ini sangat penting karena di instalasi farmasi klinik utama cideng medical center perlu adanya pengelolaan database untuk mendukung pengadaan obat dan alat kesehatan, guna memberikan informasi yang berguna bagi Tenaga Kefarmasian.

Beberapa penelitian yang pernah dilakukan mengenai fuzzy database adalah mengenai fuzzy database model tahani dalam memberikan rekomendasi pembelian rumah berbasis web. Penelitian ini berisi tentang penentuan rekomendasi pembelian rumah dengan metode Fuzzy Database model Tahani yang bertujuan agar konsumen dapat memilih rumah sesuai dengan kriteria yang dipilihnya dengan lebih cepat dan mudah. Penentuan jenis-jenis variabel dan humpunan fuzzy yang digunakan didasarkan pada hasil pengumpulan data di PT X. Dengan cara wawancara dan penyebaran angket adapun jenis- jenis Variabel dan Himpunan fuzzy : Harga (Murah,Sedang,Mahal), Uang Muka (Rendah,Sedang,Tinggi), Luas Bangunan dan Tanah (Kecil,Sedang,Luar), Lebar Jalan (Kecil,Standar,Besar), dan Jarak rumah dari Jalan Raya (Dekat, Sedang, Jauh). Kesamaran dari pertimbangan kriteria konsumen tersebut dapat dituangkan ke dalam suatu konsep logika fuzzy dengan menggunakan database yang mampu menangani kriteria-kriteria yang bersifat samar. Adapun database yang mampu menangani data dari proses query yang bersifat samar bernama fuzzy database Model Tahani, karena model database fuzzy Tahani merupakan database yang mampu memetakan suatu input data yang bersifat angka (crisp) menjadi data yang bersifat linguistik (samar)[1].

Penelitian lain adalah mengenai fuzzy database untuk statistika. Menurut hasil penelitiannya Fuzzy Database Statistikal adalah database yang digunakan untuk tujuan analisis database statistikal yang bersifat samar. Tabel statistikal kabur(samar) berisi susunan daftar tabel represnetasi dari ststistik samar dan digunakan untuk struktur data fuzzy database statistikal yang nantinya tabel tersebut bertujuan untuk memanipulasi data[2]. Penelitian mengenai prediksi jumlah kebutuhan obatpun pernah dilakukan, dimana aplikasi ini berfungsi untuk memprediksi jumlah kebutuhan obat-obatan di periode mendatang dengan memanfaatkan variabel sisa stok, pemakaian obat dan jumlah kebutuhan. Terdapat beberapa tahapan untuk menghasilkan outputan dengan metode ini diantaranya Implementasi definisi variabel, mennetukan fungsi keanggotaan, inferensi berdasarkan predikat dan menentukan nilai output crisp yang merupakan hasil akhir. Berdasarkan hasil ujicoba aplikasi yang menggunakan sample sebanyak 35 data obat PKD, terdapat 34 obat yang memiliki error rate $<25 \%$ yang artinya aplikasi prediksi ini layak digunakan. Error terkecil adalah sebesar 7,2\% dengan kata lain tingkat akurasi dari aplikasi ini adalah sebesar 92,8\% [3].

Penelitian mengenai pengadaan alat kesehatanpun pernah dilakukan diantaranya untuk puskesmas kecamatan Durenan yang masih berjalan secara manual. Penelitian ini dilakukan 
pada 2 lokasi yaitu Badan Pusat Statistik Kab. Trenggalek dan Puskesmas Durenan dengan melakukan observasi dan wawacanra dengan sumber secara langsung mengenai pokok permasalahan yang diteliti. Metode yang digunakan dalam penelitian ini adalah Analytical Hierarcy Process (AHP) untuk mengetahui jumlah stok alat dan prioritas permintaan alat kesehatan di Puskesmas Kec. Durenan secara cepat, efektif, dan efisien. Metode AHP ini digunakan untuk menentukan prioritas permintaan alat sesuai dengan bobot AHP masingmasing alat [4].

Penelitian lain yang penulis pakai adalah mengenai istem pendukung keputusan penentuan persediaan bahan baku. Sistem Pendukung Keputusan penentuan persediaan bahan baku ini bertujuan untuk memprioritaskan kelompok persediaan bahan baku yang sering digunakan dan biasanya jenisnya sedikit akan tetapi mempunyai biaya investasi yang besar. Pihak manajemen dituntut untuk dapat mengontrol jumlah persediaan sehingga bahan baku yang tersedia tidak terlalu banyak dan juga tidak terlalu sedikit. Persediaan bahan baku yang banyak akan menyebabkan biaya penyimpanan terlalu tinggi dan akan memungkinkan bahan baku menjadi rusak, namun jika persediaan bahan baku sedikit dikhawatirkan permintaan akan produk tidak dapat terpenuhi. Oleh karena itu diperlukannya pengendalian atas ketersediaan bahan baku sesuai dengan prioritasnya. Proses perhitungan yang dilakukan untuk mendapatkan jumlah persediaan bahan baku berdasarkan prioritasnya ada 4 yaitu menghitung ramalan penjualan untuk periode berikutnya (Trend Linier), menghitung jumlah bahan baku yang dibutuhkan dengan mengalikan jumlah penjualan produk dengan komposisi dari produk tersebut, mengelompokkan bahan baku berdasarkan kelasnya (Always Better Control analysis), kemudian menghitung jumlah pembelian yang optimal (Economic Order Quantity). Nilai persediaan bahan baku berdasarkan kelompok prioritas yang dihasilkan menjadi rekomendasi bagi PT. Makassar Megaprima untuk menentukan jumlah persediaan bahan baku berdasarkan kelompok prioritasnya. Hasil yang diperoleh adalah sistem yang dibangun meminimalkan jumlah pembelian pemesanan persediaan bahan baku sesuai dengan kebutuhan berdasarkan prioritas dari bahan baku tersebut[5]

\section{METODE PENELITIAN}

\subsection{Metodologi pengembangan perangkat lunak}

Pengembangan perangkat lunak yang penulis gunakan dalam penelitian ini adalah melalui pendekatan prototype. Hal ini disebabkan karena protoype dapat beradaptasi dengan ketidakpastian efisiensi algoritma yang digunakan dalam pengembangan sistem informasi yang akan dilakukan. Selain itu, dalam metode prototype dikenal juga langkah-langkah percangannya dengan:

a. Mengidentifikasikan persyaratan dasar pengguna. Para perancang sistem (biasanya para pakar sistem informasi) bekerja dengan pengguna dalam waktu cukup lama untuk mengetahui kebutuhan dasar mereka atas informasi.

b. Membuat prototipe awal. Perancangan sistem membuat prototipe yang bisa beroperasi, dilakukan secara cepat dengan menggunakan perangkat lunak generasi-keempat, multimedia interaktif, atau perangkat lunak CASE (Computer Aided Software Engineering).

c. Menggunakan prototipe. Pengguna dianjurkan menggunakan sistem prototipe untuk menentukan seberapa baik prototipe tersebut sesuai dengan kebutuhan mereka dan mereka bisa memberi saran-saran untuk lebih meningkatkan prototipe.

d. Revisi dan Perbaikan prototipe. Pembuat sistem mencatat semua perubahan yang diminta oleh pengguna dan mengatur prototipe. Setelah merevisi prototipe kembali lagi ke langkah ke-tiga. Langkah tiga dan empat bisa diulang lagi sampai pengguna merasa puas. 


\subsection{Prosedur perancangan sistem rekomendasi pengadaan obat dan alat kesehatan}

Prosedur perancangan sistem ini dapat dijadikan acuan yang dilakukan oleh pengguna atau user (apoteker dan asisten apoteker) dalam pengoprasian sistem yang dibuat, yaitu:

a. Sistem membutuhkan akses username dan password untuk dapat masuk dan mengoprasaikannya.

b. Pengolahan data seperti stok keluar atau masuk ada pada menu persediaan sistem, sedangkan untuk rekomendasi pengadaan obat dan alat kesehatan ada pada menu rekomendasi.

c. Dalam sistem untuk pencarian obat dan alat kesehatan sebagai rekomendasi pengadaan maka variable dan kategori dapat ditentukann berdasarkan standar persyaratan mutu pengadaankemudian juga dapat disesuaikan dengan kebutuhan.

d. Kemudian dari hasil olahan data menggunakan Fuzzy Database hasil tersebut dapat dicetak sebagai laporan untuk diajukan kepada direktur sebagai rekomendasi pengadaan obat dan alat kesehatan

Berdasarkan analisa prosedur diatas, maka dokumen yang didapatkan dari Insatalasi Farmasi Klinik Utama Cideng Medical Center yaitu:

a. Kartu Persediaan Obat dan Alkes yang keluar

b. Kartu Persediaan Obat dan Alkes yang masuk

c. Laporan Info Tagihan

d. Laporan Info Harga

e. Datar Distributor

Selanjutnya dari dokumen yang ada maka akan didapatkan 3 variabel yaitu:

a. Sisa Persediaan

b. Pengeluaran

c. Harga Tagihan Masuk

Dari variabel-variabel tersebut selanjutnya akan memliki kategori masing-masing yaitu:

a. Untuk Sisa Persediaan : Sedikit, Sedang, Banyak

b. Untuk Pengeluaran : Lambat, Sering, Agak Cepat, Cepat

c. Untuk Tagihan Masuk : Murah, Agak Mahal, Mahal

Dari hasil analisa dokumen yang menghasilkan informasi tersebut, kemudian akan diolah dengan Fuzzy Database akan menghasilkan informasi Rekomendasi Pengadaan Obat dan Alat Kesehatan.

\subsection{Fuzzy querry}

Fuzzifikasi query diasumsikan sebuah query konvensional (nonfuzzy) basis data yang akan mencoba membuat dan menerapkan sebuah sistem dasar logika fuzzy query (fuzzy logic based querying system). Kelebihan query fuzzifikasi yaitu dapat mencapai kelenturan (flexibility) dari database, penanganan error otomatis, pencarian yang flexibel, dan kesanggupan merespon kosong[6]. Konsep dari sebuah relasi fuzzy dalam sebuah DBMS menggunakan derajat keanggotaan $\mu$ yang didefinisikan pada kumpulan domain $X=\{X I \ldots . . X n\}$, dan telah digenerate pada relasi luar oleh nilai tengah fuzzy. Sintaks query yang digunakan adalah sebagai berikut :[8]

Select $<\mathrm{n}$ or $\mathrm{t}><$ attribute $>$ From < relations $>$ where $<$ Fuzzy condition $>$.... pers (1)

Misalkan terdapat sebuah tabel Karyawan, dimana didalamnya terdapat field-field seperti Nama, Umur, dan Gaji. Kemudian jika menggunakan sintaks SELECT NAMA FROM KARYAWAN WHERE (Umur < 40), maka data yang akan ditampilkan adalah hanya data karyawan yang memiliki umur kurang dari 40 tahun. Sedangkan jika data dari tabel diolah menggunakan operasi himpunan fuzzy, maka kondisi yang diinputkan berupa variabel linguistik, misalkan SELECT NAMA FROM KARYAWAN WHERE (Umur="MUDA") AND (Gaji = "TINGGI"). Sehingga data yang ditampilkan adalah data karyawan yang memiliki umur termasuk dalam himpunan muda fuzzy dan gaji termasuk dalam himpunan tinggi fuzzy dari table. 


\subsection{Fuzzy Tahani}

Basis data klasik hanya menangani data-data yang bersifat pasti dan tegas. Sedangkan pada kenyataannya manusia seringkali berkomunikasi dalam bahasa yang tidak jelas batasannya. Untuk menangani hal tersebut maka dibangunlah sebuah basis data dengan pendekatan logika fuzzy. Basis data yang menggunakan pendekatan fuzzy tidak hanya menyimpan dan memanipulasi fakta-fakta yang pasti tetapi juga pendapat-pendapat subjektif, keputusan dan nilai-nilai yang dapat dijabarkan dalam istilah linguistik. Pada umumnya, ada dua cara untuk memasukkan unsur kekaburan (fuzziness) ke dalam sebuah basis data, yaitu:

a. Fuzzy Database

Fuzzy database adalah basis data mempunyai kemampuan untuk menyimpan dan memanipulasi data-data yang mengandung ketidakpastian secara langsung. Artinya, pengguna memasukkan informasi-informasi yang mengandung unsur kekaburan ke dalam pangkalan data. Basis data jenis ini juga didukung oleh query yang bersifat fuzzy untuk memperoleh informasi.

b. Fuzzy Query Database

Fuzzy query database adalah membuat suatu fuzzy query terhadap basis data klasik. Pengguna membuat suatu aplikasi yang dapat menangani suatu query dimana dalam query tersebut terdapat variabel-variabel yang bernilai fuzzy atau dengan kata lain query tersebut memiliki variabel-variabel linguistik. Sedangkan data pada basis data yang akan diakses merupakan data yang bersifat pasti. Pangkalan data yang diusulkan oleh Tahani adalah bentuk dari FuzzyQuery Database. Basis data Tahani masih tetap menggunakan relasi standar, hanya model ini menggunakan teori himpunan fuzzy untuk mendapatkan informasi pada query-nya [6]. Tahani mengembangkan sebuah kerangka kerja pada level konseptual tingkat tinggi untuk memproses fuzzy query pada lingkungan basis data konvensional atau non-fuzzy. Tahani merumuskan sebuah arsitektur dan pendekatan formal untuk menangani basis data dengan fuzzy query yang sederhana. Bahasa query yang digunakan berdasarkan SQL. Program aplikasi basis data fuzzy adalah program untuk melakukan pencarian data dengan metode pencarian linguistik. Program ini merupakan penerapan dari teori tentang basis data fuzzy. Input awal dalam program ini adalah kriteria user, selanjutnya penentuan variabel fuzzy dan penentuan himpunan fuzzy akan digunakan dalam pencarian. Setelah data dimasukkan dan pengguna telah memilih kriteria pencarian pada tabel pencarian linguistik, langkah selanjutnya yaitu menghitung derajat keanggotaan suatu data di setiap himpunan pada suatu variabel berdasarkan fungsi keanggotaan yang telah dipilih sebelumnya. Selajutnya proses fire strength berdasarkan kriteria yang dipilih. Data yang memiliki nilai fire strength tertinggi menunjukkan bahwa data tersebut yang paling mendekati kriteria pencarian. Sebaliknya, data yang memiliki nilai fire strength terkecil menunjukkan bahwa data tersebut semakin menjauhi criteria pencarian. Hasil yang ditampilkan pada tab pencarian linguistik merupakan data yang mendekati kriteria pencarian dengan urutan nilai fire strength terbesar sampai nilai fire strength terkecil yang menunjukkan urutan data yang paling mendekati kriteria pencarian sampai yang paling jauh dari kriteria pencarian. Disini diasumsikan sebuah konvensional (nonfuzzy) DBMS, dan mencoba mengembangkan serta mengimplementasikan sebuah sistem logika fuzzy query. Dalam sistem logika fuzzy query ini berupaya mencapai sebuah kelenturan (flexibility) dari sebuah database yang mana mempunyai aspekaspek variasi seperti koreksi kesalahan secara otomatis, pencarian flexibel, kemampuan menghindari respon kosong, kemungkinan dari ketepatan, istilah ucapan atau sebutan dalam sebuah query. Pendekatan pertama dalam fuzzyquery ke databse adalah Tahani. Ide dari Sistem basis data fuzzy model Tahani adalah mendefinisikan konsep dari relasi fuzzy dalam sebuah DBMS dengan derajat keanggotaan. Dalam proses perekomendasian mobil yang paling sesuai bagi pengguna (calon pembeli mobil) adalah dengan menerapkan metode penelitian dengan menggunakan Fuzzy Database Model Tahani. Mobil yang direkomendasikan adalah mobil yang memiliki nilai Fire Strength atau tingkat kesesuaian dengan kriteria pilihan diatas angka 0 (nol) sampai dengan angka 1 (satu). Pada system perekomendasian mobil, diharapkan dapat membantu para calon pembeli dalam 
menentukan mobil yang paling sesuai dengan kriteria pilihannya. Dengan menggunakan metode fuzzy Tahani maka user lebih terbantu dalam menentukan pilihan mobil yang akan dibeli setelah mendapatkan beberapa rekomendasi sistem sesuai dengan nilai Fire Strengthnya [6].

\section{HASIL DAN PEMBAHASAN}

\section{a. Perancangan usecase diagram}

Sebuah UC diagram menyatakan visualisasi interaksi yang terjadi antara pengguna (aktor) dengan sistem. Diagram ini bisa menjadi gambaran yang bagus untuk menjelaskan konteks dari sebuah sistem sehingga terlihat jelas batasan dari sistem. Ada 2 elemen penting yang harus digambarkan, yaitu aktor dan UC[7]

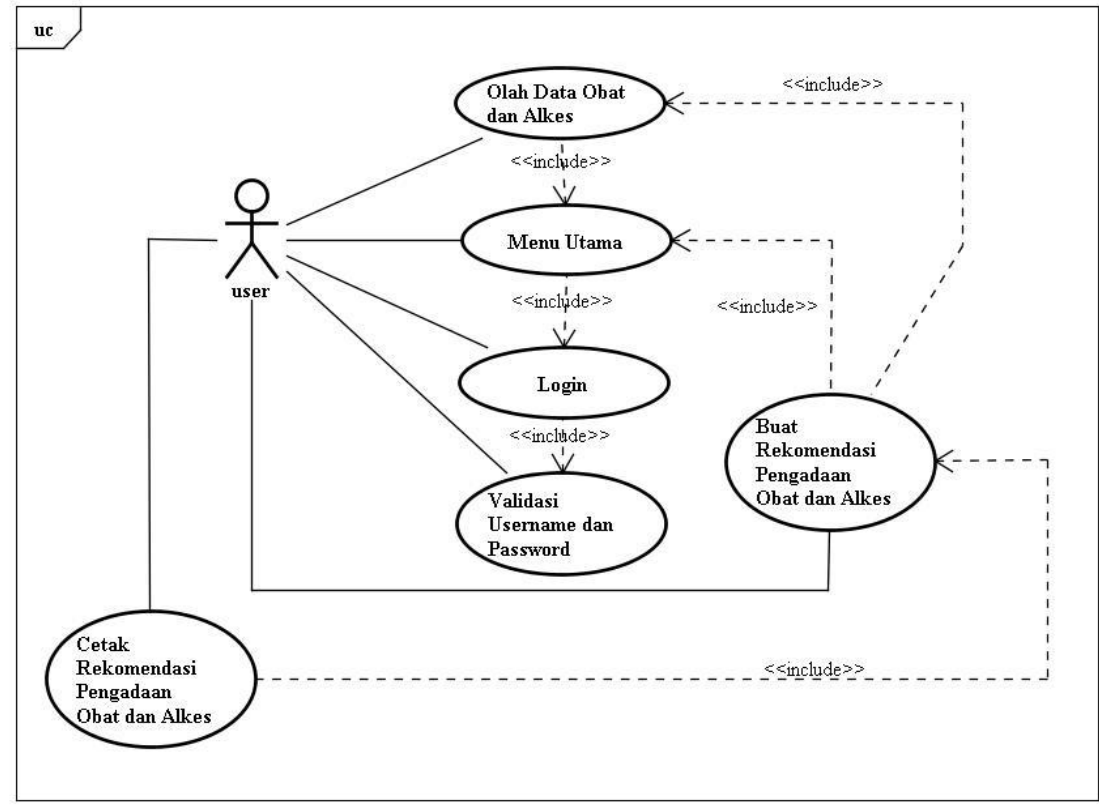

Gambar 1. Usecase diagram sistem.

Berdasarkan gambar 1, user yang akan menggunakan sistem ini adalah admin yang akan mengelola keseluruhan pengolahan data. Dimana admin tersebut dapat melakukan pengolahan data obat dan alkes, yang selanjutnya bisa langsung melakukan rekomendasi pengadaan obat dan alkes. Selain itupula admin bisa melakukan cetak laporan rekomendasi pengadaan obat dan alkes.

\section{b. Perancangan class diagram}

Meskipun dalam pembahasan ini pemodelan class dilakukan pemodelan use case, sebenarnya pada faktanya kedua aktivitas tersebut dilakukan secara paralel. Kedua model tersebut sebenarnya saling mendukung dalam pemberian informasi. Class biasanya digunakan untuk mendefinisikan obyek-obyek bisnis. Class-class seperti ini biasanya mendefinisikan model database dari suatu aplikasi[9]. Class diagram pada perancangan sistem terdapat pada Gambar 2.

\section{c. Perancangan ERD}

ERD (Entity Relationship Diagram) adalah model teknik pendekatan yang menyatakan atau menggambarkan hubungan suatu model. Didalam hubungan ini tersebut dinyatakan yang utama dari ERD adalah menunjukan objek data (Entity) dan hubungan (Relationship), yang ada 
pada Entity berikutnya.[10]. Sedangkan gambaran ERD pada perancangan sistem yang dibuat terdapat gambar 3.

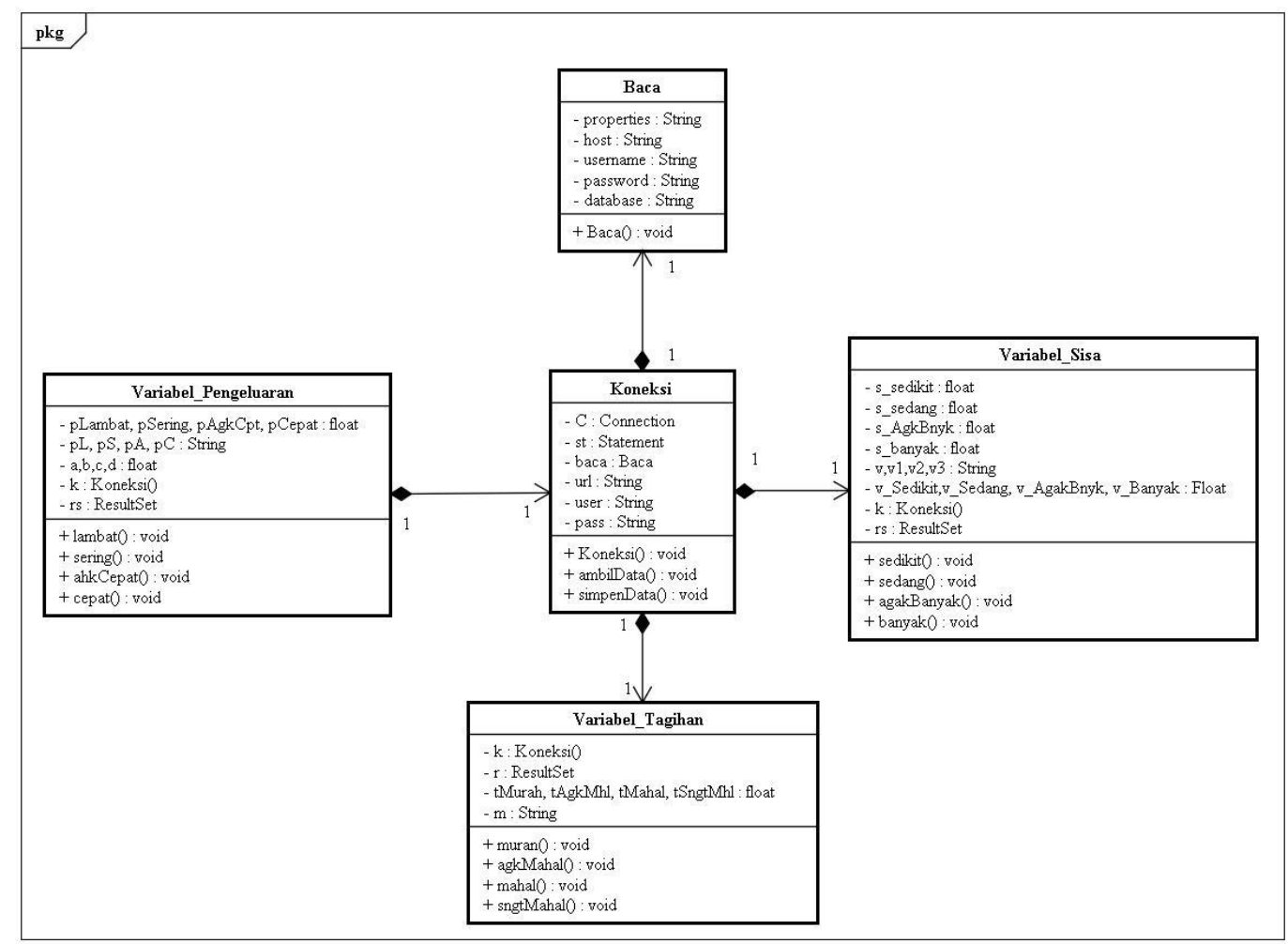

Gambar 2. Class diagram sistem.

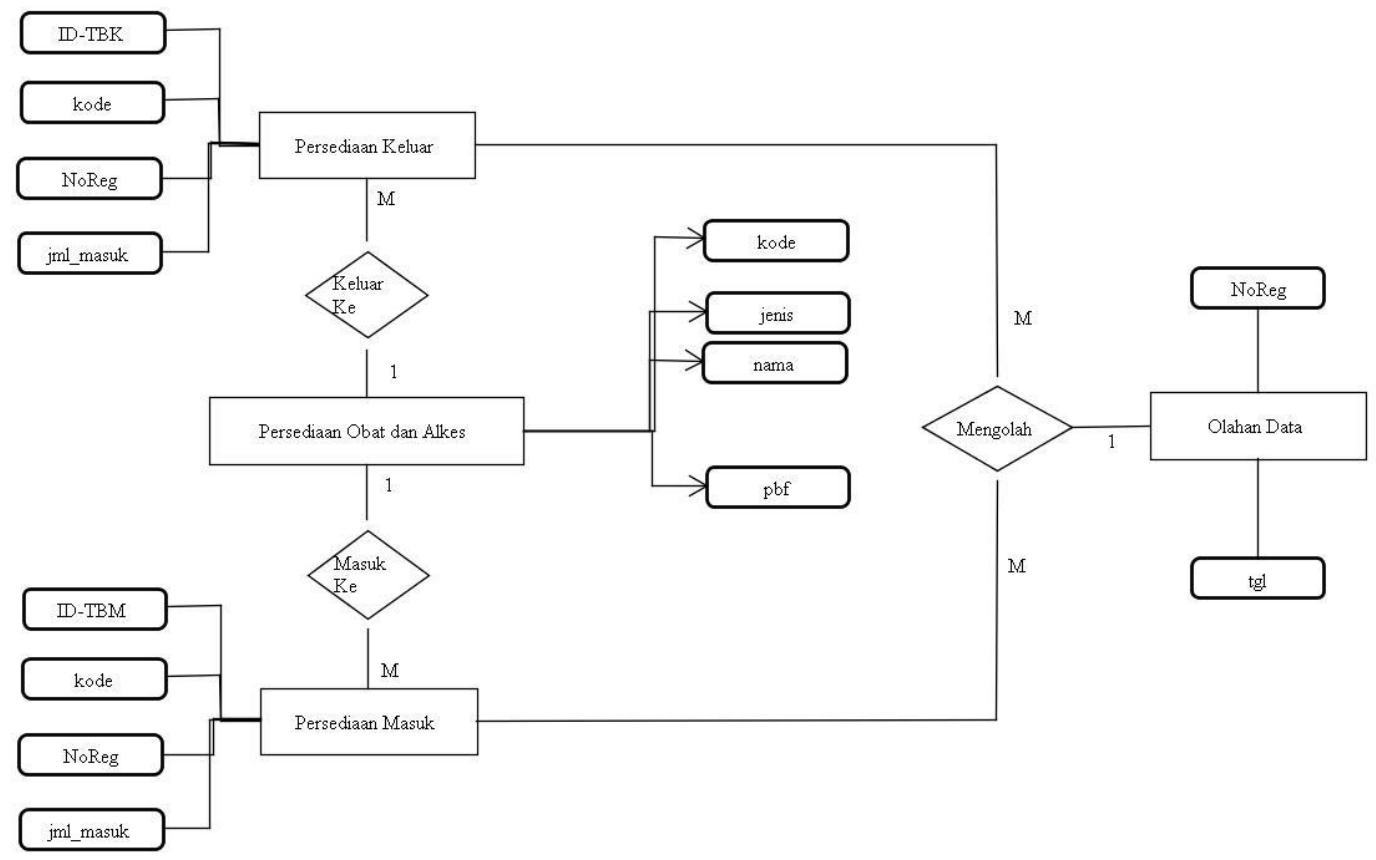

Gambar 3. ER Diagram . 


\section{d. Prosedur penentuan rekomendasi pengadaan obat dan alat kesehatan menggunakan fuzzy database}

Prosedur penentuan yaitu, langkah-langkah dan hal apa saja yang dilakukan dalam penentuan Rekomndasi Pengadaan Obat dan Alat Kesehatan, dengan tahapan Instalasi Farmasi memberikan data daftar obat dan alat kesehatan tahun 2016, yang akan diadakan setelah itu data tersebut akan dinormalisasikan, kemudian tahapan selanjutnya sebagai berikut:

1) Proses penentuan Fungsi Keanggotaan

Dalam prosedur penentuan rekomendasi setiap variabel fuzzy menggunakan fungsi keanggotaan berbentuk bahu, dan segitiga sebagai pendekatan untuk memperoleh derajat keanggotaan suatu nilai dalam suatu himpunan fuzzy.

- Variabel Sisa Persediaan

Variabel Sisa Persediaan dibagi menjadi 3 himpunan fuzzy, yaitu: SEDIKIT, SEDANG, AGAK BANYAK, dan BANYAK.Himpunan SEDIKIT, SEDANG, dan BANYAK menggunakkanpendekatan fungsi keanggotaan yang berbentuk bahu, sedangkan himpunan AGAK BANYAK mengunakan pendekatan fungsi kenaggotaan berbentuk segitiga.

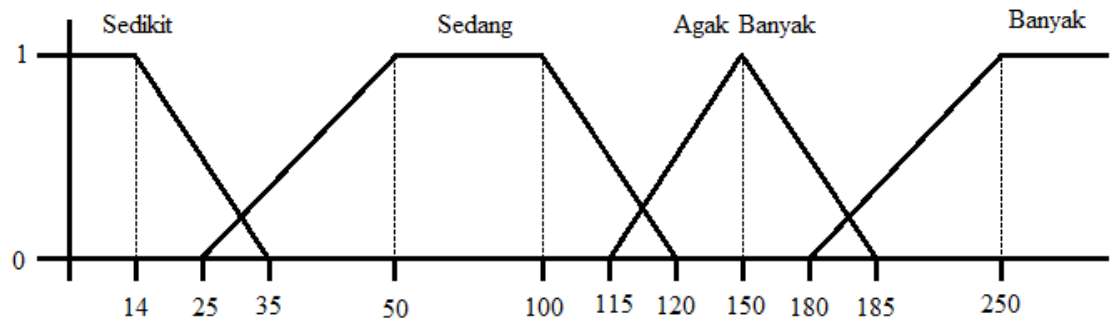

Gambar 4. Fungsi Keanggotaan pada Variabel Sisa Persediaan.

- Variabel pengeluaran

Variabel Pengeluaran dibagi menjadi 4 himpunan fuzzy, yaitu: LAMBAT, SERING,

AGAK CEPAT, CEPAT. Himpunan tersebut menggunakan pendekatan fungsi keanggotaan yang berbentuk bahu

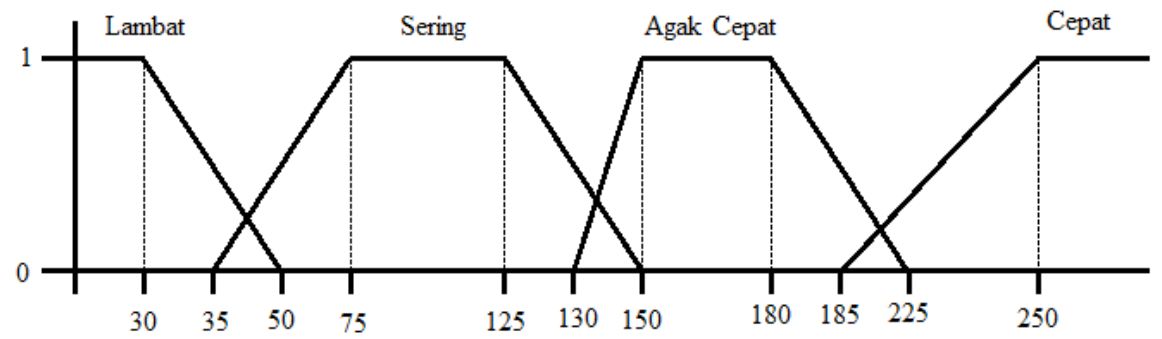

Gambar 5. Fungsi Keanggotaan pada Variabel pengeluaran

- Variabel banyak tagihan masuk

Variabel Banyak Tagihan Masuk merupakan variabel yang dipengarugi oleh persediaan masuk, dan juga isi kemasan obat dan alkes kemudian dibagi menjadi 3 himpunan fuzzy, yaitu: MURAH, AGAK MAHAL, MAHAL, SANGAT MAHAL. Himpunan MURAH dan MAHAL menggunakan pendekatan fungsi keanggotaan yang berbentuk segitiga, sedangkan untuk AGAK MAHAL dan SANGAT MAHAL menggunakan pendekatan fungsi keanggotaan berbentuk bahu. 


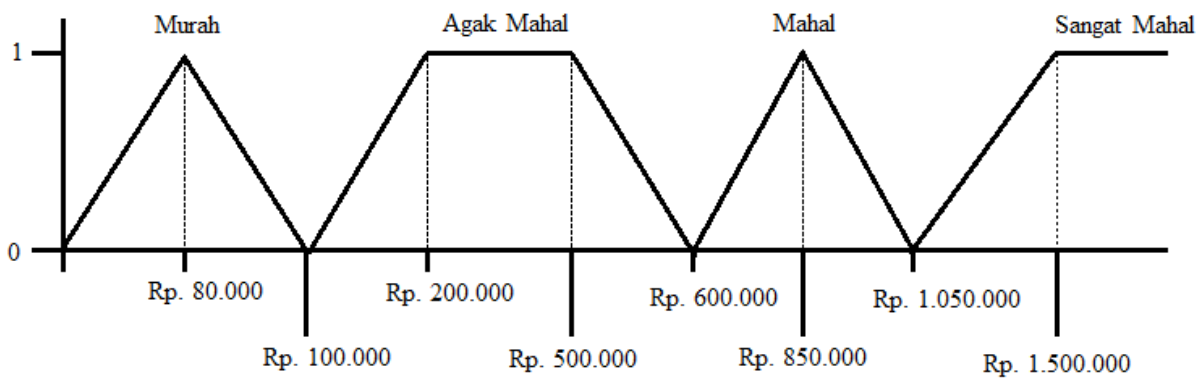

Gambar 6. Fungsi Keanggotaan pada Variabel banyak tagihan masuk

2) Proses perhitungan

Proses perhitungan dimulai dari penentuan merumuskan untuk setiap masing-masing variabel fungsi keanggotaan kemudian hitung daftar obat dan alkes terhadap variabel fungsi keanggotaan. Tabel 1 merupakan hasil perhitungan derajat keanggotaan daftar obat dan alkes pada variabel sisa persediaan.

Tabel 1. Hasil Perhitungan Derajat Keanggotaan Daftar Obat dan Alkes pada Variabel Sisa Persediaan

\begin{tabular}{|c|c|c|c|c|c|c|c|}
\hline \multirow{2}{*}{ No } & \multirow{2}{*}{ ID } & \multirow{2}{*}{ Nama } & \multirow{2}{*}{ Sisa } & \multicolumn{4}{|c|}{ Derajat Keanggotaan $(\mu[\mathrm{x}])$} \\
\cline { 5 - 8 } & & & & SEDIKIT & SEDANG & AGAK BANYAK & BANYAK \\
\hline 1 & FT010 & INLACTA 500 DHA & 195 & 0 & 0 & 0 & 0,21 \\
\hline 2 & F03170 & PRESTRENOL TAB & 218 & 0 & 0 & 0 & 0,54 \\
\hline 3 & A00742 & SPUIT 1 CC TUBER & 41 & 0 & 0,64 & 0 & 0 \\
\hline 4 & F80023 & ONE SWABS 70\% & 142 & 0 & 0 & 0,77 & 0 \\
\hline 5 & F870P & VIT K 1 ML & 38 & 0 & 0,52 & 0 & 0 \\
\hline
\end{tabular}

Sedangkan Tabel 2 merupakan hasil perhitungan derajat keanggotaan daftar obat dan alkes pada variabel pengeluaran.

Tabel 2. Hasil Perhitungan Derajat Keanggotaan Daftar Obat dan Alkes pada Variabel pengeluaran

\begin{tabular}{|c|c|l|c|c|c|c|c|}
\hline \multirow{2}{*}{ No } & \multirow{2}{*}{ ID } & \multirow{2}{*}{ Nama } & \multirow{2}{*}{ Keluar } & \multicolumn{4}{|c|}{ Derajat Keanggotaan $(\mu[\mathrm{x}])$} \\
\cline { 5 - 8 } & & & & LAMBAT & SERING & AGAK CEPAT & CEPAT \\
\hline 1 & FT010 & INLACTA 500 DHA & 277 & 0 & 0 & 0 & 1 \\
\hline 2 & F03170 & PRESTRENOL TAB & 441 & 0 & 0 & 0 & 1 \\
\hline 3 & A00742 & SPUIT 1 CC TUBER & 0 & 1 & 0 & 0 & 0 \\
\hline 4 & F80023 & ONE SWABS 70\% & 10 & 1 & 0 & 0 & 0 \\
\hline 5 & F870P & VIT K 1 ML & 0 & 1 & 0 & 0 & 0 \\
\hline
\end{tabular}

Dan Tabel 3 merupakan hasil perhitungan derajat keanggotaan daftar obat dan alkes pada variabel harga tagihan masuk.

Tabel 3. Hasil Perhitungan Derajat Keanggotaan Daftar Obat dan Alkes pada Variabel harga tagihan masuk

\begin{tabular}{|c|c|c|c|c|c|c|c|c|c|c|}
\hline \multirow[b]{2}{*}{ No } & \multirow[b]{2}{*}{ ID } & \multirow[b]{2}{*}{ Nama } & \multirow[b]{2}{*}{ Masuk } & \multirow[b]{2}{*}{$\begin{array}{c}\text { Isi } \\
\text { Kemasan }\end{array}$} & \multirow[b]{2}{*}{ HNA } & \multirow{2}{*}{$\begin{array}{c}\text { Harga Tagihan } \\
\text { (Masuk/Isi } \\
\text { Kemasan) }{ }^{*} \text { HNA }\end{array}$} & \multicolumn{4}{|c|}{ Derajat Keanggotaan $(\mu[\mathrm{x}])$} \\
\hline & & & & & & & MURAH & $\begin{array}{r}\text { AGAK } \\
\text { MAHAL }\end{array}$ & MAHAL & $\begin{array}{l}\text { SANGAT } \\
\text { MAHAL }\end{array}$ \\
\hline 1 & FT010 & INLACTA 500 DHA & 300 & 30 & Rp 135.000 & 1.350 .000 & 0 & 0 & 0 & 0,67 \\
\hline 2 & F03170 & PRESTRENOL TAB & 400 & 50 & Rp180.000 & 1.440 .000 & 0 & 0 & 0 & 0,87 \\
\hline 3 & A00742 & SPUIT 1 CC TUBER & 0 & 100 & Rp110.000 & $R p$ & 0 & 0 & 0 & 0 \\
\hline 4 & F80023 & ONE SWABS $70 \%$ & 0 & 100 & Rp 23.100 & $\mathrm{Rp}$ & 1 & 0 & 0 & 0 \\
\hline 5 & F870P & VIT K 1 ML & 0 & 100 & Rp131.818 & $\mathrm{Rp}$ & 1 & 0 & 0 & 0 \\
\hline
\end{tabular}


3) Hasil proses rekomendasi

Setelah Proses peritungan berdasarkan perumusan fungsi keanggotaan pada masing-masing variabel hasil yang didapatkan adalah berupa kemungkinan kombinasi pilihan, karena setiap variabel fuzzy terbagi atas 4 himpunan, dan kemungkinan membebaskan kategori (tidak memilih himpunan apapun). Dengan demikian, banyaknya kombinasi pilihan kategori ke tiga variabel fuzzy adalah $5^{3}=125$ kombinasi pilihan. Oleh karena itu pilihan yang digunakan sebagai sample yaitu: Harga Tagihan MURAH dan pengeluaran LAMBAT dan Sisa Persediaan SEDIKIT, kemudian ambil nilai Minimun dari kategori tersebut maka didapat hasil seperti Tabel 4.

Tabel 4. Hasil proses rekomendasi

\begin{tabular}{|c|c|c|c|c|c|c|c|c|c|c|c|c|}
\hline \multirow[b]{2}{*}{ No } & \multirow[b]{2}{*}{ ID } & \multirow[b]{2}{*}{ Nama } & \multirow[b]{2}{*}{ Masuk } & \multirow[b]{2}{*}{ Keluar } & \multirow[b]{2}{*}{ Sisa } & \multirow[b]{2}{*}{$\begin{array}{c}\text { Isi } \\
\text { Kemasan }\end{array}$} & \multirow[b]{2}{*}{ HNA } & \multirow{2}{*}{$\begin{array}{c}\text { Harga Tagihan Masuk } \\
\text { (Masuk/Isi Kemasan) * } \\
\text { HNA }\end{array}$} & \multicolumn{4}{|c|}{ Derajat Keanggotaan $(\mu[\mathrm{x}])$} \\
\hline & & & & & & & & & MURAH & I LAMBAT & SEDANG & $\begin{array}{c}\text { MURAH \& LAMBAT } \\
\text { \& SEDANG }\end{array}$ \\
\hline 1 & FT010 & INLACTA 500 DHA & 300 & 277 & 195 & 30 & Rp 135.000 & 1.350 .000 & 0 & 0 & 0 & 0 \\
\hline 2 & F03170 & PRESTRENOL TAB & 400 & 441 & 218 & 50 & Rp180.000 & 1.440 .000 & 0 & 0 & 0 & 0 \\
\hline 3 & A00742 & SPUIT 1 CC TUBER & 0 & 0 & 41 & 100 & Rp110.000 & $\mathrm{Rp}$ & 0 & 1 & 0,64 & 0 \\
\hline 4 & F80023 & ONE SWABS $70 \%$ & 0 & 10 & 142 & 100 & Rp 23.100 & $\mathrm{Rp}$ & 1 & 1 & 0 & 0 \\
\hline 5 & F870P & VIT K $1 \mathrm{ML}$ & 0 & 0 & 38 & 100 & Rp131.818 & Rp & 1 & 1 & 0,52 & 0,52 \\
\hline
\end{tabular}

4) Rekomendasi pengadaan obat dan alkes

Berdasarkan Hasil yang didapat dari lima sampel daftar obat dan alkes kemudian juga kategori yang ditentuka makan satu item alkes dengan nama VIT K 1ML di rekomendasi untuk di lakukan pengadaan persediaan dan juga sebagai laporan

\section{KESIMPULAN}

Dari penelitian yang penulis lakukan dapat diambil beberapa kesimpulan bahwa dengan menggunakan metode Fuzzy Database sebagai pencarian di sistem database dianggap pengadan akan lebih mudah, cepat dan tepat sasaran sesuai standar kualitas mutu. Selain itu penggunaan metode Fuzzy Database berimbas ketersediaan informasi yang hasilkan untuk tenaga kefarmasian dalam peningkatan palayanan.

\section{SARAN}

Adapun saran dari penelitian ini adalah Pengembangan sistem Rekomendaasi Pengadaan Obat dan Alat Kesehatan akan lebih baik lagi jika ditambahkan dengan sistem stok opname. Selain itu variabel dan himpunan yang digunakan akan lebih baik jika ditingkatkan menjadi lebih banyak sehinngga akan lebih akurat dan presisi.

\section{DAFTAR PUSTAKA}

[1] Efendi, Rusdi. Ernawati. Hidayati R. "Aplikasi Fuzzy Database Model Tahani Dalam Memberikan Rekomendasi Pembelian Rumah Berbasis WEB". Jurnal Pseudocode Vol.1 No.1 Februari 2014, p.32-43 [Online]. Available: https://ejournal.unib.ac.id/index.php/pseudocode/article/view/60/40

[2] Guglani, S. Katti, C.P. "A language for fuzzy statistical database”. International journal of Database Management System (IJDMS) Vol.5 No.1 Februari 2013. P.69-64 [Online]. Available : http://airccse.org/journal/ijdms/papers/5113ijdms06.pdf

[3] Ulinnuha, Zulfa. "Prediksi Jumlah Kebutuhan Obat-Obatan Menggunakan Metode Fuzzy Tsukamoto (Studi Kasus Dinas Kesehatan Kabupaten Malang”. Skripsi Jurusan Teknik Informatika Fakultas Sains dan Teknologi Universitas Islam Negeri Maulana 
Malik Ibrahim Malang [Online]. Available : http://etheses.uinmalang.ac.id/7551/1/08650066.pdf

[4] Pratama, Freddy. "Sistem Pendukung Keputusan Pengadaan Alat Kesehatan di Puskemas Kecamatan Durenan Menggunakan Metode AHP”. Skripsi Program Studi Teknik Informatika Fakultas Teknik Universitas Nusantara PGRI Kediri 2017 [Online]. Available http://simki.unpkediri.ac.id/mahasiswa/file artikel/2017/12.1.03.02.0161.pdf

[5] Yahya, Kurnia. Nasaruddin. "Sistem Pendukung Keputusan Penentuan Persediaan Bahan Baku". Jurnal InfoSys Vol.2 No.1 Februari 2013 P.64-79 [Online]. Available : http://riset.potensi-

utama.ac.id/upload/penelitian/penerbitan jurnal/2689sistem pendukung keputusan pen entuan_persediaan_bahan_baku.pdf

[6] Kusumadewi, Sri. Heri, Purnomo. "Aplikasi Logika Fuzzy untuk Pendukung Keputusan”. Graha Ilmu Yogyakarta 2014

[7] Kurniawan TA. "Pemodelan Usecase (UML): Evaluasi Terhadap Beberapa Kesalahan Dalam Praktik". Jurnal Teknologi Informasi dan Ilmu Komputer (JTIIK) Vol.5 No.1 Maret 2018 [Online]. Av7-86 Available: http://jtiik.ub.ac.id/index.php/jtiik/article/download/610/pdf

[8] Hamdani. Hivaluddin. Muhammad Syarif Abdilllah. "Sistem Pendukung Keputusan Pembelian Notebook Menggunakan Logika Fuzzy Tahani”. Jurnal Informatika Mulawarman Vol.6 No.3 September 2011 [Online]. Available: http://ejournals.unmul.ac.id/index.php/JIM/article/view/80/pdf

[9] Gushelmi, Kamda DR. "Pemodelan UML Sistem Penerimaan Mahasiswa Baru Berbasis WAP (Studi Kasus Sistem Penerimaan Mahasiswa Baru UPI YPTK Padang”. Jurnal Ilmu Komputer Vo.1 No.1 Oktober 2012 [Online]. Available : http://jik.htp.ac.id/index.php/jik/article/download/5/2/

[10] Fridayanthie EW, Mahdiati T. "Rancang Bangun Sistem Informasi Permintaan ATK Berbasis Internet (Studi Kasus Kejaksaan Negri Rangkasbitung". Jurnal Khatulistiwa Informatika Vol.IV No.2 Desember 2016 [Online]. Available : https://ejournal.bsi.ac.id/ejurnal/index.php/khatulistiwa/article/viewFile/1264/1029 